\title{
Three Horsemen of the Apocalypse for Human Resources in China
}

\author{
Jun Feng \\ $\mathrm{PhD}$. Candidate in labor economics at the Graduate School \\ Chinese Academy of Social Sciences \\ Beijing, China
}

\begin{abstract}
Through empirical analysis, this paper considers that the three considerable human resource challenges faced by organizations in China, respectively, are lack of understanding for strategic human resources management, insufficiency in human resources development, and drying-up of human capital. In order to overcome and tackle the first two challenges, the main suggestions of practices and strategies are to establish the high-performance human resource management system and corporate university.
\end{abstract}

Keywords-SHRM; human resources development; human capital

\section{INTRODUCTION}

China, nowadays, is the world's second-largest economy. Though China's economy has been growing rapidly since the implementation of the reform and opening-up policy, organizations in China, inevitably, are facing tremendous challenges from human resources because of the process of extensive and profound changes in the field of not only enterprise's microcosmic administration structure but also the economic transition and demographic characteristics.

In the three decades of reform and opening, China have been keeping nearly two-digital increasing rate of economy. In the past, the source of economic growth considerably came from the reallocation of all kinds of production factors which mainly included the transferring surplus rural workforce and the opening for private industrial capital. Lin et al. (1998) generalized the development strategy and economic reform as the China Miracle.

Small and medium-sized enterprises grew rapidly after the opening for private capital in consumer and light industries which did not exist during the era of the plan economy in China. While they are enjoying the bonus of cheap payroll costs because of the infinite supply of labor in China, the human resources management level of organizations, from the average and the overall sense, however, is still in the stage of extensive management in quite a long period of history in the past and in the near future.

After the Lewis Turning Point in 2004 and the disappearance of China's demographic dividend in 2010 (Cai $\& \mathrm{Du}, 2011$ ), Chinese corporations experienced the rapid increase of labor costs and caught in the trap of comparative advantage vacuum (Cai et al., 2002). In the last five years, China's economy has entered into the new normal from highlevel growth to medium-high-level growth. The slowdown in economic growth made human resource challenges faced by organizations in China become even more exposed. The three main barriers of the HRM for Chinese corporations are lack of understanding for strategic management of human resources, insufficiency in human resources development and training, and the drying-up of human capital pool.

\section{HuMAN RESOURCE CHALLENGES}

\section{A. Lack of Understanding for SHRM}

The most issue in the field of human resources management faced by organizations in China nowadays might be that lack of clear awareness with strategic meaning of HRM. There are a number of historical and practical conditions can account for this challenge from all types of perspectives. In my opinion, however, the most considerable and profound reason is that human management of Chinese organizations, generally and averagely, is still following the ideology, systems, methods and techniques of traditional personnel management from the age of the plan economy in China even though the policy of reform and opening-up has implemented more than 30 years.

According to a survey of HR managers of Chinese corporations from Accenture $(\mathrm{ACN})$ in 2011, one of the barriers which restrains Chinese enterprises to become excellence and tend towards internationalization is that companies have poor abilities of strategic planning and management, especially, in the aspect of human resources management of not only HR managers but also line managers (CAIXIN, 2011). In other words, a significant number of Chinese enterprises are difficult to become bigger and stronger, in large part due to lack of clear strategies that should have combined with those human resource management practices concerning to enterprises' long-term development.

The survey of ACN found that $12.8 \%$ of respondents believed that strategic objectives of HRM of their enterprises were not clear. The survey revealed that most of Chinese enterprise payed more attention to traditional performance indicators, e.g., employee turnover rate, when mapping out human resource planning. The deficiency of comprehensive and profound discussions of the strategic positioning of 
enterprises' HRM and specific measures concerning to how to achieve these strategic objectives, unfortunately, is obvious.

In addition, the questionnaire also showed that $8.1 \%$ of interviewee pointed out that the Chinese organization's strategic objective of HRM, typically, is too abstract to operate. And $31.8 \%$ of respondents thought that their enterprises did not appraise and evaluate the implementation status of human resource strategic planning. Last but not the least, $11.4 \%$ of interviewee considered that the strategic HR plans of their corporations were not clear and detailed. Therefore, accordingly, they were difficult to implement without directions for practical operation.

All in all, the neglect of the integration between strategic objectives and human resources management, significantly, is a restrictive factor for Chinese enterprises in the process of the transition of human resources management model from traditional personnel management whose characteristics are institutional control and material incentives to modern human resources management oriented by organization strategy.

\section{B. Insufficiency in HRD}

The second main problem facing Chinese organizations is that human resources development (HRD) and on-the-job training are seriously inadequate. Similarly, traditional personnel management pays too little attention to HRD and training because organization just require the simple duplication of labor during the era of the plan economy.

In 2012, an investigation with representativeness around the country was conducted by Institute of education, Tsinghua University aiming to grasp the training situation and effect of organizations' staff in China. Six companies which included Yiyang Rubber, Sha-Long-Da, Changyi Petrifaction, Fengshen Tyre, Haohua Aerospace, and Yuxing Co., Ltd. were selected finally based on Probability Proportionate to Size Sampling (PPS) "Fig. 1".

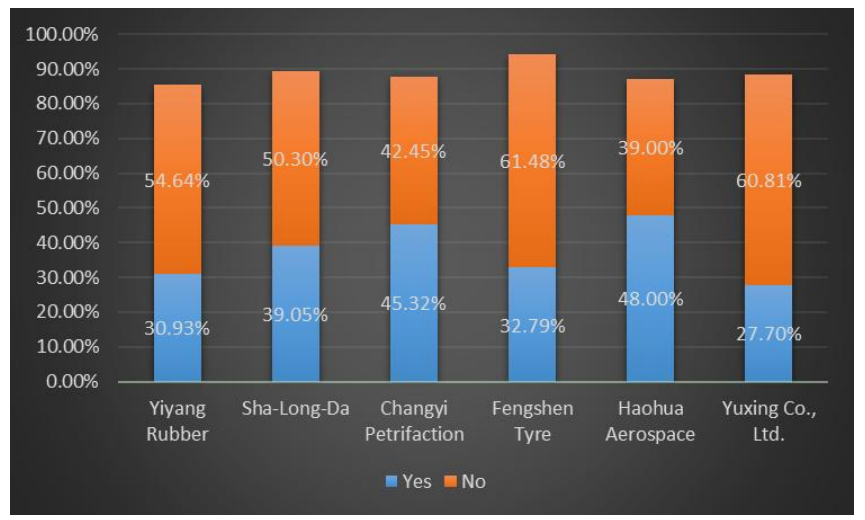

Fig. 1. Whether to participate in job training (by group). Data Sources:

Institute of education, Tsinghua University

According to this survey, the situation is not optimistic concerning to the HRD and on-the-job training from the perspective of the percentage of training received. Number of staff who have never been formally trained on the job was more than the number of employee getting benefits from any forms of HRD. Owing to lack of the experience about HRD and on-the-job training, return of human resources investment, demonstrably, might become a stubborn vicious cycle which is puzzled by staff and enterprises "Fig. 2".

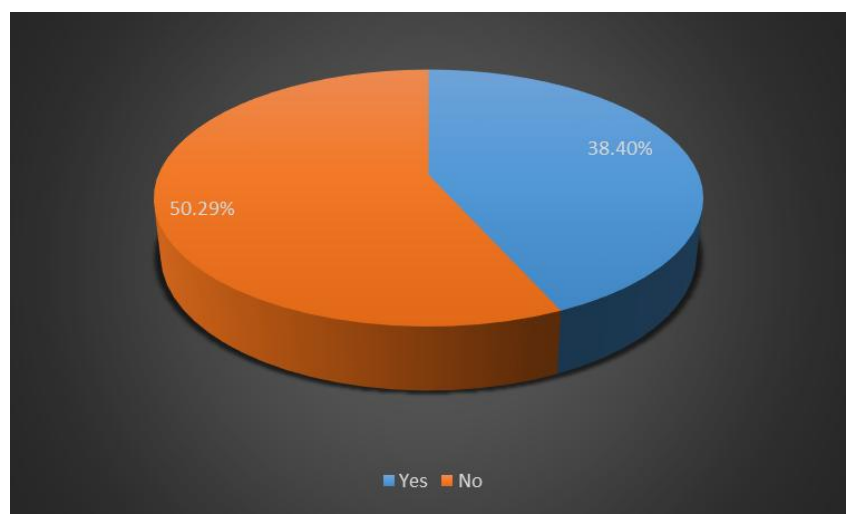

Fig. 2. Whether to participate in job training (overall). Data Source: Institute of education, Tsinghua University

In terms of a more prospective analysis angle of view, the awareness of HRD often matters more than the training experience in the past for employee. The staff's degree of understanding for on-the-job training, judging from the current sample analysis, however, did not fare much better. The share of individuals who had an understanding of company's training program were slightly more than one third as a whole "Fig. 3".

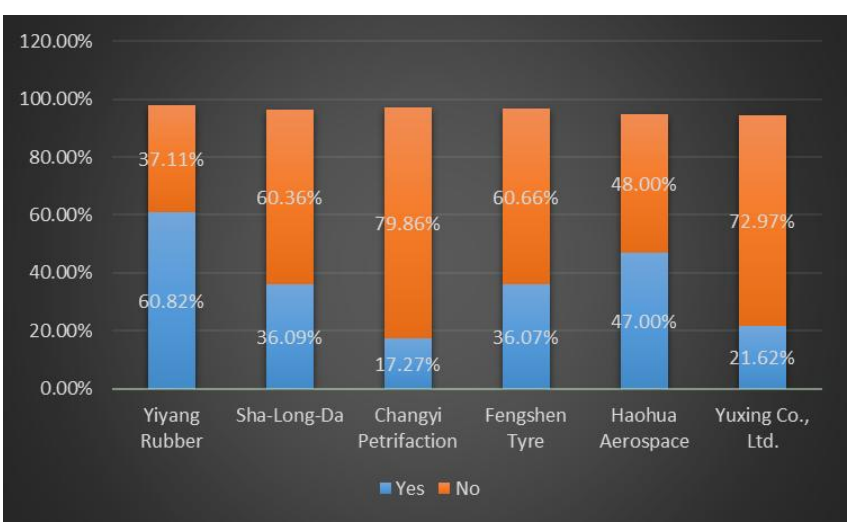

Fig. 3. Do you know about job training in your company (by group). Data Source: Institute of education, Tsinghua University

This kind of thinking is extremely dangerous. Because it is considerably difficult for workers to measure their own actual demands and expectations of HRD and training better if they had no idea concerning to training programs that employers could provide "Fig. 4". 


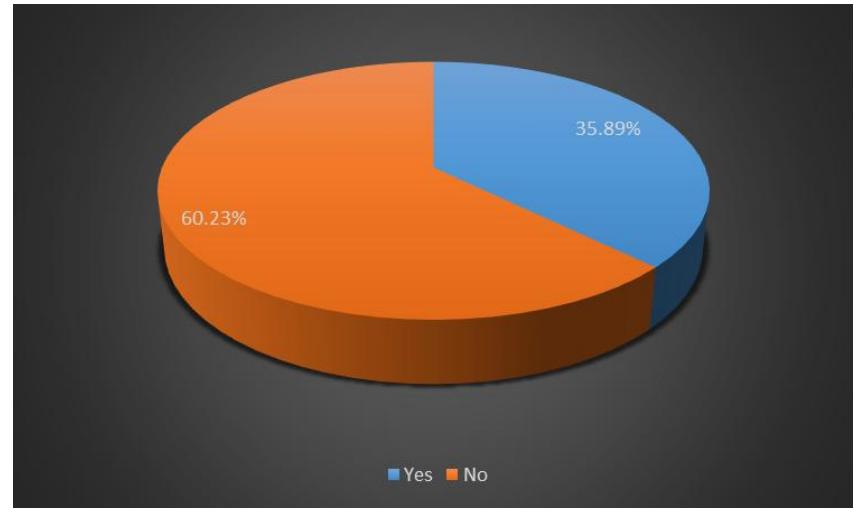

Fig. 4. Do you know about job training in your company (overall). Data Source: Institute of education, Tsinghua University

All in all, there are serious deficiency in the field of human resources development for Chinese organizations and their HRM practice. The process of industrial structural transformation and value chain upgrading might face great resistances and uncertainty if staff's human capital level, which which is often represented by knowledge and skills,

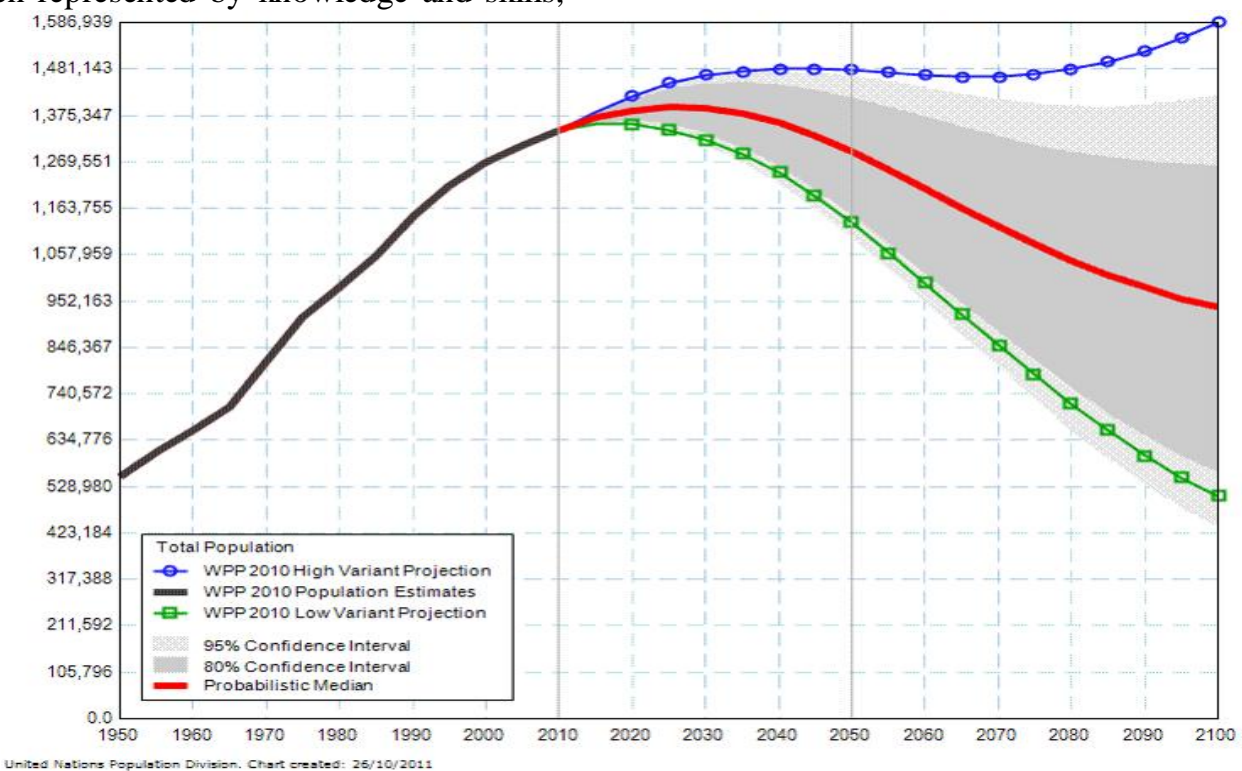

Fig. 5. The Population Prediction of China. Data Source: United Nations Population Fund (UNPF).

According to the prediction from United Nations Population Fund (UNPF), China's population peak will appear on one year between 2020 and 2030 depending on changes of policy of birth control and total fertility rate, TFR. Although the two-child fertility policy for couples where either the husband or the wife is from a single-child family and the universal two-child policy have implemented, it is almost impossible that the TFR may rebound to more than 2.1 which is described as replacement level (Cai, 2004). That means HR may be having to work harder just to get professionals to accept job opportunities they have to offer as time goes by. If things go on like this, moreover, the processes of enlarging production for enterprises in China are bound to be seriously affected at least from human resources "Fig. 6". can't be updated timely. Ultimately, this disadvantage originated in human resource management will weaken the competitiveness and potential of China's economic growth in the long run.

\section{Drying-up of Human Capital}

A considerably difficult problem faced by organizations in China, nowadays and during a long period of future time, is the drying-up of human capital because of demographic changes. China's demographic dividend, which has been considered as a significant growth engine of China before, has been disappearing since 2012 (Cai \& Du, 2015), which will have significant impact on economic growth. Concerning to both quantity and quality of the labor pool in China, as we known, rapid decrease of the working-age population and the slowdown of the improvement of human capital that usually come along with former means that there are a significant number of limitations for $H R$ and organizations in aspects of recruitment, wage bargaining, human resource development, and so forth "Fig. 5".

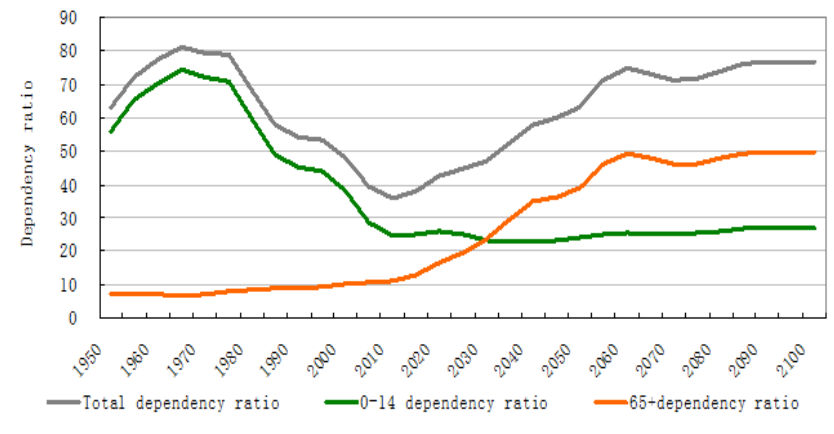

Fig. 6. Dependency Ratio of China. Data Source: United Nations Population Fund (UNPF) 
Besides the decrease in working age population, the challenge of population rise in dependency ratio may be more considerable with the inevitability of changing from demographic bonus to demographic debts. Owing to the pressures on social security contribution, employee are bound to require more generous salaries and benefits. The organization and its human resource department, however, will gradually lose the bargaining power in the labor market facing the shrinkage of labor poor "Fig. 7".

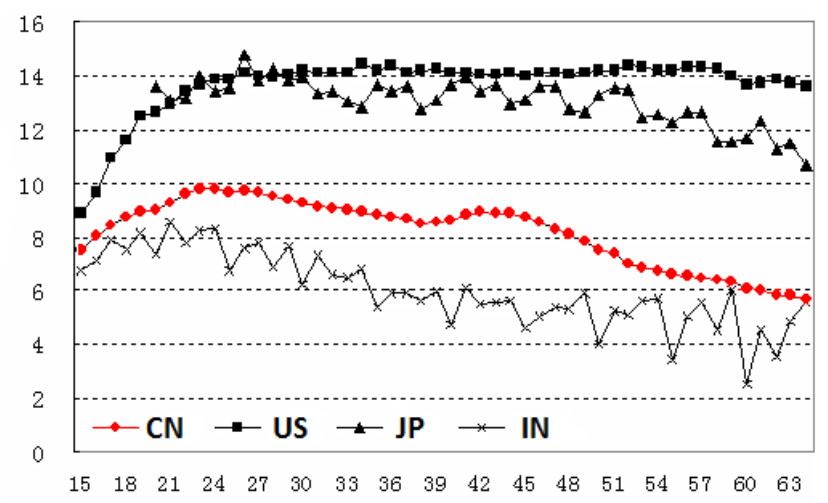

Fig. 7. Education Years for Age of CN, US, JP and IN. Data Source: World Bank

In comparison with the decrease of quantity of labor force, troubles from the perspective of labor force quality may be more intractable. As shown in the figure, there is disparity between China and developed countries such as America and Japan in education years for age. Originally, this gap can be diminishing with the improvement of the education of young people. However, the aged tendency of population will interpret this behavior. In other words, the improvement of human capital also will be forced to discontinue. In the long run, therefore, it has become more difficult to finish the process of industrial structure reformation and promotion of China.

\section{PRACTICES AND STRATEGIES}

\section{A. High-performance Human Resource Management System}

For Chinese enterprises, the key is to build a highperformance human resource management system (HPHRMS) if they want to fill the gap between human resource management and organization's strategy.

First of all, there is a positive effect of HPHRMS on strategic management capacity. According to Resourcebased Theory, HR of enterprises is a source of competitive advantage (Pferffer, 1985). However, quality resources of the enterprise in China, nowadays, do not necessarily mean the competitive advantages of these corporations. Competitive advantages finally depend on the implementation of quality resources in the process of the strategic management which are composed of strategic analysis, strategy formulation and strategic actualization that is particularly significant. HRM affects the competence of the strategic implementation through human capital features which are needed by the strategic working method that can provide particular business practices for the incorporation and employees performance as a strategic asset in the whole process of the implementation of strategy. Therefore, Chinese corporations should build HPHRMS as soon as possible to improve their strategic management capacities.

Second of all, Chinese enterprises should make the best of the strategic management capacity as the mediating mechanism of the effect of HPHRMS on enterprise performance. A significant issue which attracts HR managers is the mechanism by which HPHRMS affects the enterprise performance (Batt, 2002; Becker \& Huselid, 2006). This interesting topic initiates a series of theories and empirical researches concerning the mediating mechanism of the effect of HRM on corporation performance (Pfeffer, 1985; Youndt \& Snell, 2004). Becker \& Huselid (2006) discussed the probability of uncovering this Black Box viz. the mediating mechanism of the influence of HPHRMS on enterprise performance. The top management leaders from not only line departments but also HR departments of Chinese companies, unlikely, can be aware of the importance of HR strategy sufficiently until they actually realize that the strategic management capacity is a significant mediating mechanism of the effect of HPHRMS on enterprise performance.

Finally, the internal motive force by which Chinese enterprises have an incentive to finish the reform and build the HPHRMS ultimately is that there is a positive correlation between HPHRMS and enterprise performance. Theoretical models and empirical evidences that there is a positive correlation between HPHRMS and enterprise performance are considerably plentiful. According to accepted practice from case study in China (Kim et al., 2010), the arithmetic mean of diverse practices of HPHRM should be viewed as the value of variable of HPHRMS in the corporation. Of course, the transition of HRM for organizations in China is no easy task but imperative under such a circumstance in which traditional personnel management disconnecting with business strategy has become more and more unsuitable to meet the requirements of modern human resource management.

\section{B. Corporate University}

As mentioned previously, Chinese organizations, especially many large state-owned enterprises in China, not only invest insufficiently in human resource development for a long time since planned economy times, but also have all sorts of problems when it comes to employee training's patterns and institutions, and all those problems has hindered these companies severely from developing. Therefore, learning organization is still a new concept. And according to western corporate management theories, a strong institution of human resource management and training can efficiently insist corporate to develop their human capital and raise employee's competence. With the development of corporate strategic management theories, it has been a common phenomenon among modern company to put learning organization to work and to push every corporate member to keep learning and participating training as long as they work in the enterprise. 
A corporate university is any educational entity that is a strategic tool designed to assist its parent organization in achieving its goals by conducting activities that foster individual and organizational learning and knowledge (Allen, 2002). Since the 21st century, the number of private universities have increased to more than 2000 (Nixon \& Helms, 2002). According to statistics from Dealtry (2004), these corporate universities are widely distributed in United States, Britain, Germany, Japan, and so forth.

The essence of the feasibility lies in two significant critical factors: returns on this type of human capital investment and Who Will Pay. Viewing the situation from a whole, a deeper meaning of these two aspects, significantly, is whether corporate university can improve the productivity level of workers in China "Table I".

TABLE I. REGRESSION ANALYSIS FOR INCOME AND TRAINING

\begin{tabular}{|c|l|l|l|l|}
\hline Variable & \multicolumn{2}{|c|}{ Prob $>$ F $=\mathbf{0 . 0 0 0 0}$} & \multicolumn{2}{c|}{$\begin{array}{c}\text { Adj R-squared }= \\
\mathbf{0 . 3 4 4 3}\end{array}$} \\
\hline income & \multicolumn{1}{|c|}{ Coef. } & \multicolumn{1}{|c|}{ Mean } & \multicolumn{1}{|c|}{ Min } & \multicolumn{1}{|c|}{ Max } \\
\hline training & $\begin{array}{l}84.941^{* *} \\
(42.768)\end{array}$ & 0.502 & 0 & 1 \\
\hline sex & $\begin{array}{l}240.084^{* * *} \\
(50.931)\end{array}$ & 0.747 & 0 & 1 \\
\hline age & $\begin{array}{l}13.963 \\
(39.202)\end{array}$ & 35.729 & 28 & 48 \\
\hline age^2 & $\begin{array}{l}0.221 \\
(0.529)\end{array}$ & 1323.349 & 784 & 2304 \\
\hline education & $\begin{array}{l}120.188^{* * *} \\
(11.767)\end{array}$ & 14.235 & 9 & 19 \\
\hline C1 & $\begin{array}{l}212.267^{* * *} \\
(81.361)\end{array}$ & 0.111 & 0 & 1 \\
\hline C2 & $\begin{array}{l}340.005 * * * \\
(71.234)\end{array}$ & 0.193 & 0 & 1 \\
\hline C3 & $\begin{array}{l}803.038^{* * *} \\
(80.057)\end{array}$ & 0.159 & 0 & 1 \\
\hline C4 & $\begin{array}{l}540.636^{* * *} \\
(78.853)\end{array}$ & 0.139 & 0 & 1 \\
\hline C5 & $\begin{array}{l}-99.504^{* * *} \\
(68.889)\end{array}$ & 0.228 & 0 & 1 \\
\hline
\end{tabular}

a. Note: *,**,*** are significant at $10 \%, 5 \%$ and $1 \%$ level respectively.

Based on empirical data from Institute of education, Tsinghua University previously mentioned, the result of regression analysis shows that there is a significant positive correlation between income and training via a similar wage equation of Mincer (1958), ceteris paribus. Specifically, a trained employee can earn an extra 84.941 yuan a month compared with individual who have not been trained. Among the regression model, age ${ }^{\wedge}$ means the square of age and $\mathrm{C} 1$ to $\mathrm{C} 5$, respectively, indicates the dummy variable reflecting individual characteristics of different companies with Yuxing Co., Ltd. as the baseline.

Through the above empirical analysis, the implication is that corporate university shows the feasibility and promise in the process of improving the HRD for Chinese organizations. Moreover, fortunately, the seed of corporate university has sprouted in China. Nowadays, China University of Chemical Engineering, which is the temporary name of the corporate university that SINOCHEM prepares to construct in the near future, has been stimulated into substantial operation.

\section{CONCLUSION}

In summary, the three considerable human resource challenges faced by organizations in China are lack of understanding for strategic human resources management, insufficiency in human resources development, and dryingup of human capital. In order to overcome the first two shortcomings, the main suggestions of practices and strategies are to establish the high-performance human resource management system and corporate university.

\section{REFERENCES}

[1] Allen M. The corporate university handbook : designing, managing, and growing a successful program[M]. AMACOM, 2002.

[2] Batt R. Managing Customer Services: Human Resource Practices, Quit Rates, and Sales Growth[J]. Academy of Management Journal, 2002, 45(3):587-597.

[3] Becker B E, Huselid M A. Strategic human resources management: where do we go from here?[J]. Journal of Management, 2006, 32(32):898-925.

[4] Cai F. Demographic Transition,Population Dividend,and Sustainability of Economic Growth:Minimum Employment As A Source of Economic Growth[J]. Population Research, 2004.

[5] Cai F, Du Y. The Social Protection System in Ageing China[J]. Asian Economic Policy Review, 2015, 10(3):250-270.

[6] Cai F, Yang Du. Wage increases, wage convergence, and the Lewis turning point in China[J]. China Economic Review, 2011, 22(4):601610.

[7] Cai F, Wang D, Du Y. Regional disparity and economic growth in China: The impact of labor market distortions[J]. China Economic Review, 2002, 13(2-3):197-212.

[8] Dealtry R. Achieving integrated performance management with the corporate university[J]. Journal of Workplace Learning, 2004, 17(1/2):65-78.

[9] Kim S, Wright P M, Su Z. Human resource management and firm performance in China: A critical review[J]. Asia Pacific Journal of Human Resources, 2010, 48(1):58-85.

[10] Lin J Y, Cai F, Li Z. The China Miracle: Development Strategy and Economic Reform[J]. China Journal, 1998, 32(39):233-235.

[11] Mincer J. Investment in Human Capital and Personal Income Distribution Author(s)[J]. Journal of Political Economy, 1958, 66(4):281-281.

[12] Nixon J C, Helms M M. Corporate universities vs higher education institutions[J]. Industrial \& Commercial Training, 2002, 34(4):144150 .

[13] Pfeffer J. Competitive Advantage Through People: Unleashing the Power of the Work Force[M]// Facing the Holocaust: Jewish Publication Society, 1985:747-749.

[14] Youndt M A, Snell S A. Human resource configurations, intellectual capital, and organizational performance.[J]. Journal of Managerial Issues, 2004, 16(3)(:3):337-360. 